\title{
ЛІНГВОДИДАКТИЧНІ ОСНОВИ ФОРМУВАННЯ КОМПЕТЕНТНОСТЕЙ МІЖКУЛЬТУРНОЇ КОМУНІКАЦІЇ СТУДЕНТІВ-ІНОЗЕМЦІВ У ПРОЦЕСІ НАВЧАННЯ УКРАЇНСЬКОЇ МОВИ
}

Костюк С. С. Лінгводидактичні основи формування компетентностей міжкультурної комунікації студентів-іноземців у процесі навчання української мови.

У статті порушено актуальні проблеми формування багатокультурної мовної особистості для рівноправної участі в міжкультурному спілкуванні. Проаналізовано погляди науковців на досліджувану проблему, схарактеризовано мету навчання іноземних громадян, основні підходи, принципи, методи та прийоми вивчення української мови як іноземної. Виокремлено комплекс вправ i методів для формування компетентностей міжкультурної комунікації студентів-іноземців у процесі навчання української мови на основному етапі навчання.

Ключові слова: українська мова як іноземна, студенти-іноземці, підходи в навчанні, методи навчання, компетентності міжкультурної комунікації.

Костюк С. С. Лингводидактические основы формирования компетентностей межкультурной коммуникации студентов-иностранцев в процессе изучения украинского языка.

В статье затронуты актуальные проблемы формирования многокультурной личности для равноправного участия в межкультурном общении. Проанализированы взгляды ученых на исследуемую проблему, охарактеризованы основные подходы, принципы, методы и приему изучения украинского языка как иностранного. Выделено комплекс методов и упражнений для формирования компетентностей межкультурной коммуникации студентов-иностранцев в процессе обучения украинскому языку на основном этапе обучения.

Ключевые слова: украинский язык как иностранный, студенты-иностранцы, подходы в обучении, методы обучения, компетентности межкультурной коммуникации.

Kostyuk S. S. Linguo-didactic bases of foreign students' intercultural communication competencies formation in studying the Ukrainian language.

Increasing the number of foreign students in Ukrainian high educational institutions has promoted the development of methods of teaching Ukrainian as a foreign language. For this purpose "The concept of language training for foreign students in Ukrainian high educational institutions" has been developed. It has been defined that the aim of language training of foreign citizens is to meet the demand of communication in different areas, such as scientific, socio-political, socio-cultural, colloquial; harmonious development of personality capable to the intercultural dialogue. A lot of textbooks and teaching aids were

(C) С. С. Костюк, 2016. 
published. But the issues of development of methods and techniques of teaching Ukrainian as a foreign language, their adaptation to the changing life conditions are still topical.

The analysis of scientific literature shows that extralinguistic, system, communicative, functional, person-centered, complex, competency-based, cultural approaches are applied to the development of intercultural communication of foreign students. Among the didactic principles scientists identify the principles of awareness, sequence, accessibility, systematic and consistency, demonstrativeness, combination theory with practice. Direct, audio-lingual, practical, communicative, read methods are used for the realization of goals, objectives and content of education. According to the above principles and methods of teaching foreign students Ukrainian the following exercises such as communicative, conditional-communicative and non-communicative are divided. At the same time to develop foreign students' intercultural communication competencies the exercises aimed at intercultural awareness and perception improvement, culture comparison, communicative competence formation in intercultural situations are used.

Key words: Ukrainian as a foreign language, foreign students, educational approaches, teaching methods, intercultural communication competencies.

Виведення освітньої галузі України на рівень розвитку розвинених країн - це сучасна тенденція українського суспільства. Євроінтеграційні зміни в Україні посприяли припливу студентівіноземців, та підвищили інтерес до пізнання української мови, літератури та культури зокрема. Статус української мови як державної розширив не тільки сферу іiі вживання, а й збільшив попит на іiі вивчення як серед громадян України так і серед іноземних студентів.

Збільшення контингенту студентів-іноземців у вишах України наприкінці XX століття послугувало поштовхом для розвитку методики викладання української мови як іноземної. Розроблено «Концепцію мовної підготовки іноземців у ВНЗ України» (Н. Ушакова, В. Дубічинський, О. Тростинська). Визначено мету мовної підготовки іноземних громадян - забезпечення комунікативної потреби у різних сферах спілкування: науковій, суспільно-політичній, соціальнокультурній, побутовій, виховання гармонійної особистості здатної до міжкультурного діалогу [10, с. 138]. Укладено підручники і посібники для студентів-іноземців. Але на сьогодні i досі залишаються актуальними питання розробки методів i прийомів викладання української мови як іноземної, пристосування їх до нестабільних умов життя, укладання підручників і посібників для іноземних громадян. 
Проблемні питання у галузі викладання української мови як іноземної знайшли своє відображення у працях таких дослідників: 3. Бакум, Л. Бєй, І. Жовтоніжко, Т. Єфімова, А. Кулик, Т. Лагута, Б. Сокіл, О. Тростинська, Г. Тохтар та ін. О. Коваленко, С. Можар, Л. Олійник висвітлювали питання використання інноваційних технологій під час викладання іноземних мов.

Існує багато методів і підходів викладання української мови як іноземної, проте вибір того чи того методу має залежати від групи студентів. Так Л. Паламар та О. Тростинська поділяють студентів залежно від мети їхнього навчання: іноземні студенти-філологи; іноземні студенти-не філологи; іноземні студенти або громадяни, що бажають вивчати мову поглиблено (спецкурси); іноземці, що опановують українську мову для потреб бізнесу, туризму. Кожна група різниться кількістю годин, терміном навчання, методами та прийомами, які використовуються для досягнення мети.

Для якісного засвоєння української мови як іноземної необхідно визначити правильний підхід. Аналізуючи підходи до вивчення української мови як іноземної, Г. Строганова виокремлює: екстралінгвістичний, системний, навчання вмінням мовленнєвої діяльності, комунікативний, функційний, діяльнісний, індивідуальний, особистісний, комплексний, компетентнісний, культурологічний [9, с. 173-179]. Кожен 3 перерахованих підходів має як переваги так і недоліки, тому очевидно, що застосування одного з підходів не дасть бажаного результату, тому за таких умов доцільним є використання комплексного підходу, що має на меті набір ефективних методів навчання, комплекс видів вправ мовленнєвої діяльності для досягнення цілей навчання.

Вимоги до організації, забезпечення та ефективності навчального процесу базуються на принципах. Серед загальних дидактичних принципів науковці (І. Бім, Б. Лапідус, 3. Курлянд, А. Семенова, Р. Хмелюк, В. Попков) виокремлюють принципи науковості, систематичності й послідовності, міжпредметних зв'язків, 
професійної спрямованості, наочності, доступності, диференціації, індивідуалізації, створення позитивної мотивації до навчання, зв'язку теорії й практики 3 життям, врахування вікових, соціально-етичних та індивідуальних особливостей студентів.

Аналіз наукових праць (3. Бакум, О. Горошкіна, В. Дороз, С. Караман, М. Пентилюк, Г. Передрій) дозволяє виокремити ті принципи, які $€$ основними для розвитку компетентностей міжкультурної комунікації студентів-іноземців у процесі навчання української мови. До таких доцільно віднести дидактичні принципи: свідомості, наступності, доступності, систематичності й послідовності, наочності, зв'язку теорії з практикою, науковості.

Принцип свідомості забезпечує цілеспрямоване усвідомлення та сприйняття мовних явищ, осмислений підбір мовного та мовленнєвого матеріалу відповідно до ситуацій та мети спілкування. Застосування принципу розвиває здатність студентів до зіставлення мовних систем (рідної та української), що забезпечує ефективне засвоєння матеріалу [2, с. 106]. Задля полегшення сприйняття й засвоєння української мови використовується принцип доступності. На думку С. Ніколаєвої, навчальний матеріал та завдання повинні співвідноситися з рівнем сформованості україномовної комунікативної компетентності, та спиратися на знання, навички та вміння вже набуті студентам-іноземцями [5, с. 49].

Принцип наступності у навчанні за твердженням А. Богуш, М. Вашуленко, В. Дороз, М. Пентилюк означає погодженість і взаємозв'язок усіх щаблів навчально-виховного процесу.

Принцип систематичності та послідовності (Ю. Бабанський, М. Данилов, К. Ушинський) передбачає систематичне та послідовне вивчення лексичних одиниць, а також їхнє регулярне повторення, навчальний процес планується 3 урахуванням раніше вивченого матеріалу та засвоєних знань.

Принцип зв'язку теорії 3 практикою (Ю. Бабанський, M. Данилов, С. Мединський, Д. Ушинський) спрямований на ๑) С. С. Костюк, 2016. 
підкріплення теоретичного матеріалу прикладами й ситуаціями 3 реального життя.

Принцип науковості (Ф. Буслаєв, В. Загороднова, Л. Щерба) вимагає закономірного зв'язку між змістом науки й навчальним предметом. Мовні знання підкріплюються фактами 3 культурним складником, що відображають культурні цінності та світосприйняття народу.

Серед основних методичних принципів науковці (Н. Баришніков, I. Бім, Є. Верещагін, Б. Лапідус, С. Ніколаєва, Ю. Пассов, М. Щербаков) виокремлюють: комунікативний, домінуючої ролі вправ, урахування рідної мови, взаємопов'язаного навчання мови і культури, автентичності навчальних матеріалів, професійної спрямованості навчання, взаємопов'язаного навчання видів мовленнєвої діяльності. В. Біблер, Ю. Дешерієва, В. Сафонова називають принцип навчання іноземної мови в контексті діалогу культур одним з основних у рамках соціокультурного підходу. 3-поміж перелічених принципів суттєвими для розвитку компетентностей міжкультурної комунікації $є$ принципи комунікативності, урахування рідної мови студентів, урахування лінгвістичного досвіду, контрастивний, культурного співнавчання, текстоцентризму.

Формування багатокультурної мовної особистості для рівноправної участі у міжкультурному спілкуванні є основною метою принцу комунікативності. І. Бім, О. Леонтьєв, Ю. Пассов розглядають поняття комунікативності як спрямованість на мовлення як форму спілкування. Основними характеристиками принципу є умотивованість висловлювань, їх спрямування на конкретну особу, ситуативність, варіативність, емоційне забарвлення. Застосування принципу комунікативності забезпечує не тільки використання різних форм роботи студентів, але й засвоєння та повторення лексичного матеріалу.

Аналіз взаємозв'язків рідної та іноземної мови дає можливість не тільки визначити об'єм труднощів, що можуть з'явитися у процесі вивчення іноземної мови, але й зробити позитивний перенос з рідної 
мови деяких автоматизованих мовленнєвих дій. Ф. Буслаєв, І. Зимня, О. Леонтьєв, Л. Щерба приділяли увагу принципу врахування рідної мови студентів під час вивчення іноземної та зазначали, що використання цього принципу дає змогу усвідомити невідповідності мовних явищ, а згодом і подолати інтерферуючий вплив рідної мови [13, с. 112].

Принцип контрастивного вивчення мов (Є. Верещагін, В. Гумбольдт, Б. Лапідус, О. Потебня, О. Реформатський, Л. Щерба,) передбачає вивчення мови через системне порівняння з іншою задля виявлення специфіки та полегшення засвоєння мовних та екстралінгвістичних засобів передачі інформації. Зіставляються не лише мовні явища, але й соціокультурна інформація (порівняння етикету, норм поведінки представників різних народів, країнознавча інформація).

У дослідженнях М. Бахтіна, В. Виноградова, 3. Бакум, С. Карамана, Т. Ладиженської, М. Пентилюк, Л. Щерби особливе місце посідає принцип текстоцентризму. Принцип заснований на єдності мовної, полікультурної та комунікативної компетенції. Л. Ларіонова, зазначає, що текстоцентричний підхід реалізовується в таких напрямках: текст - засіб пізнання мови як поліфункціонального явища; залучає до вивчення української культури; на його основі відбувається вивчення граматичних категорій, мовних явищ; $\epsilon$ важливим інструментом у процесі оволодіння чотирма видами мовленнєвої діяльності; є основою для створення реальних ситуацій спілкування [3].

Принцип професійної спрямованості у навчанні студентівіноземців знаходить своє відображення у працях Т.Гаврюшенко, Л. Суботи, Н. Філяніної, В. Циганенко. Принцип полягає в оволодінні професійно зорієнтованими знаннями, уміннями та навичками.

Отже, орієнтованість на професійну спрямованість у процесі вивчення української мови студентами-іноземцями сприяє формуванню системи знань, умінь та навичок необхідних для подальшого навчання та застосування у практичній діяльності.

Для успішного оволодіння іноземною мовою важливу роль відіграють методи навчання, які застосовуються для реалізації мети, (๔) С. С. Костюк, 2016. 
завдання, змісту навчального процесу, та підпорядковані вирішенню конкретного завдання. Сьогодні існує багато класифікацій методів навчання іноземних мов, які обумовлені метою і змістом навчання: характеризують діяльність викладача і студента (І. Бім, Ф. Рабінович, Г. Рогова, Т. Сахарова); характеризують способи взаємодії викладача i студента (О. Бєляєв, В. Мельничайко, М. Пентилюк, С. Караман); залежно від використання перекладу в навчанні (Т. Капітонова, Л. Московкін, А. Щукін).

На нашу думку, процесу формування компетентностей міжкультурної комунікації студентів-іноземців у процесі вивчення української мови на основному етапі навчання найбільш відповідають: прямий метод (М. Берліц, Ф. Гуєн, О. Єсперсен, Ш. Швейцар, В. Фієтор); аудіолінгвальний (Ч. Фріз, Р. Ладо); свідомо-практичний (запропонований Б. Бєляєвим); комунікативний (У. Литлвуд, Г. Уідоусан, Ю. Пассов, Г. Піфо); метод читання (М. Уест). Розглянуті методи дозволяють залучати у процес навчання не лише мовні аспекти, а культурні й країнознавчі, що сприяє осмисленому оволодінню мовного матеріалу, полегшує формування мовних та мовленнєвих навичок та умінь.

Методи реалізуються у вправах, спрямованих на відпрацювання конкретного завдання, виконання яких $є$ необхідним для досягнення кінцевої мети. Проблемам створення ефективної системи вправ присвячено праці Л. Гегечкорі, I. Зимньої, Г. Китайгородської, Ю. Пассова, Г. Рогової, С. Шатілова, А. Щукіна. В основу тієї чи тієї класифікації лінгводидакти покладають критерії: ступінь перетворення інформації (Н. Гез), можливість забезпечити вживання елементів мови (Б. Лапідус), підновленість висловлення (Н. Обносов), етапи формування мовленнєвого вміння (Ю. Пассов) та інші.

Залежно від виду роботи І. Рахманов виокремив три види вправ: а) мовні та мовленнєві вправи; б) пов'язані і не пов'язані з текстом; в) перекладні та без перекладні вправи. Беручи до уваги особливості виучуваної лексики та мету іiі засвоєння, науковець виокремлює 
критерії, яких необхідно дотримуватися, добираючи вправи для розвитку лексичних навичок: необхідність репродуктивного або рецептивного засвоєння слів; зростання труднощів; різнобічна робота над словом; зв'язок із засвоєними раніше словами [8].

Розробник комунікативного підходу Ю. Пассов класифікував вправи спираючись на етапи розвитку мовленнєвих навичок. Згідно 3 цим критерієм він поділив їх на: а) вправи для формування навичок (умовно-мовленнєві); б) вправи для розвитку умінь (мовленнєві) [7].

Ураховуючи мету навчання іноземної мови С. Шатілов пропонує ввести вправи: а) комунікативні (реалізують акт мовленнєвої діяльності); б) умовно-комунікативні (комунікація відбувається у середовищі, що імітує природнє); в) некомунікативні (не пов'язані 3 мовленнєвою діяльністю, спрямовані на розвиток мовних навичок) [12, с. 55-58].

Згідно з критерієм спрямованості вправи на прийом або видачу інформації С. Ніколаєва розрізняє такі види вправ: рецептивні; репродуктивні; рецептивно-репродуктивні; продуктивні; рецептивнопродуктивні [5, с. 67-68].

Розробляючи вправи для навчання усного мовлення, Н. Гез спирається на три принципи: 1) послідовність формування мовленнєвих вмінь та навичок передбачає застосування мовних та мовленнєвих вправ; 2) типи вправ пов'язані між собою і можуть застосовуватися на будьякому етапі навчання; 3) вибір тих чи тих вправ, в межах кожного типу, ïх частотність залежить від етапу навчання. Спираючись на ці принципи науковець виокремлює мовні (імітування, перебудова інформації) та мовленнєві (підготовлене та непідготовлене висловлювання) вправи. Першу групу поділяють на аналітичні; тренувальні; вправи з елементами навчальної мовленнєвої комунікації. Другу групу складають мовленнєві вправи та навчально-мовленнєві (вправи, що імітують мовленнєву комунікацію в навчальних умовах) [1, с. 78-81].

У межах формування міжкультурної компетенції С. Бахманн, С. Герхолд та Г. Весслінг розподіляють вправи на чотири блока:

(c) С. С. Костюк, 2016. 
1. Розвиток міжкультурної поінформованості та сприйняття. До блоку входять наступні вправи: опис та коментар побаченого чи почутого; робота з малюнком, розповідь історії (за малюнком); оцінка ситуації; опис людини (за зразком), опис малюнка (на пам'ять).

2. Висловлювання думки. До цього блоку належать вправи націлені на пошук спільних для двох культур понять (виключення невідповідних слів, розмова про спільні речі, находження критеріїв для спільних понять, формулювання питань про спільні поняття, проектна робота над спільними поняттями).

3. Порівняння культур. Вправи спрямовані на порівняння та знаходження різниці у двох культурах (знаходження спільного, класифікація, обговорення деталей, порівняння соціокультурних компонентів, порівняння стереотипів).

4. Формування комунікативної компетенції в ситуації міжкультурного спілкування. Вправи передбачають аналіз комунікаційних стратегій та власне комунікацію (аналіз та порівняння виразів, переклад, активне аудіювання, міжкультурну взаємодію, дискусію по ролям, переказ) [14, с. 71-91].

Погодимося $з$ думкою О. Ломакіної яка зауважує, що вправи на розвиток міжкультурної компетентності повинні спиратися на комунікативну компетенцію яку вже мають студенти; ураховувати позанавчальні інтереси студентів; розвивати незалежність висловлювань; долучати до вирішення проблемних завдань; поєднувати розвиток чотирьох видів мовленнєвої діяльності; виявляти та розуміти міжкультурні відмінності; залучати різноманітні форми взаємодії; базуватися на автентичних текстах; застосовувати різноманітні мовні матеріали [4]. У працях С. Фоломкіної значна увага приділяється читанню, як рецептивному виду мовленнєвої діяльності. Науковець виокремлює ознайомлювальне, пошукове, переглядове та вивчаюче читання [11, с. 31$]$.

Отже, для розвитку компетентностей міжкультурної комунікації студентів-іноземців застосовують екстралінгвістичний, системний, 
комунікативний, функційний, діяльнісний, індивідуальний, особистісний, комплексний, компетентнісний, культурологічний підходи. Серед дидактичних принципів виокремлюють принцип свідомості, наступності, доступності, систематичності й послідовності, наочності, зв'язку теорії з практикою, науковості. Для реалізації мети, завдання та змісту навчання використовують методи: прямий, аудіолінгвальний, свідомо-практичний, комунікативний, метод читання.

Відповідно до вказаних вище принципів і методів навчання української мови в іншомовній аудиторії виокремлюють комунікативні, умовно-комунікативні та некомунікативні вправи. Водночас для формування компетентностей міжкультурної комунікації застосовують вправи направлені на розвиток міжкультурної поінформованості та сприйняття, порівняння культур, формування комунікативної компетенції в ситуації міжкультурного спілкування.

\section{Література}

1. Гез Н. И. Методика обучения иностранным языкам в средней школе / Гез Н. И., Ляховицкий М. В., Миролюбов А. А., Фоломкина С. К., Шатилов С. Ф. - М. : Высшая школа, 1982. $-373 \mathrm{c}$.

2. Зимняя И. А. Психология обучения неродному языку / И. А. Зимняя. - М. : Русский язык, 1989. -219 с.

3. Ларионова Л. Г. Методика преподавания русского языка [Электронный ресурс] / Л. Г. Ларионова. - М. : Просвещение, 2010 Подходы и принципы обучения русскому языку. - Режим доступа : http : // proffi95.ru/blogs

4. Ломакина О. Е. Проективность в методике формирования коммуникативной компетенции студентов языкового вуза : [монография] / О. Е. Ломакина. - Волгоград : Перемена, 2003. - 298 с.

5. Методика навчання іноземних мов у середніх навчальних закладах : [підручник] / [Бігич О. Б., Бражник Н. О., Гапонова С. В. та ін.] ; під керів. С. Ю. Ніколаєвої. - К. : Ленвіт, 1999. - 320 c.

6. Паламар Л. М. Лінгводидактичні основи формування україномовної особистості / Л. М. Паламар. - К. : НПЦ «Київський університет», 1997. - 235 с.

7. Пассов Е. И. Основы коммуникативной методики обучения иноязычному общению / Е. И. Пассов. - М. : Русский язык, 1989. - 276 с.

8. Рахманов И. В. Основные направления в методике преподавания иностранных языков в 19-20 в. / И. В. Рахманов. - М. : Педагогика, 1972. - 318 с.

(c) С. С. Костюк, 2016. 
9. Строганова Г. Концептуальні підходи до засвоєння української мови іноземними студентами / Г. Строганова // Теорія і практика викладання української мови як іноземної : зб. наук. праць. - Львів, 2008. - Вип. 3 - С. 173-179.

10. Ушакова Н. І. Концепція мовної підготовки іноземців у ВНЗ України / Ушакова Н. І., Дубічинський В. В., Тростинська О. М. // Викладання мов у вищих навчальних закладах на сучасному етапі. Міжпредметні зв’язки : зб. наук. праць. Харків, 2011. - Вип. 19. - С. 136-146.

11. Фоломкина С. Ф. Обучение чтению на иностранном языке в неязыковом вузе : [учеб.-метод. Пособие] / С. Ф. Фоломкина. - М. : Высшая школа, 2005. - 255 с.

12. Шатилов С. Ф. Методика обучения немецкому языку в средней школе : [учеб. пособие] / С. Ф. Шатилов. - М. : Просвещение, 1986. - 223c.

13. Щерба Л. В. Преподавание языков в школе : Общие вопросы методики : [учебное пособие] / Л. В. Щерба. - [3-е изд., испр. и доп]. - М. : Академия, 2002. - 160 с.

14. Bachmann S. Aufgaben und Ubunfstypologie zum interkulturellen / Bachmann S., Lernen Gerhold S., Wessling G. // Zielsprache Deutsh 27. - Soest : Landesinstitut fur Schule. - 1996. - P. 77-91.

Стаття надійшла до редакиії 16.11.2016 p. 